\title{
A poda de árvores sob o olhar da limpeza urbana na Cidade do Rio de Janeiro
}

\author{
José Henrique Rabello Penido Monteiro \\ Companhia Municipal de Limpeza Urbana / PMRJ \\ Engenheiro,jpenido@web-resol.org
}

\section{RESUMO}

Expõe o problema da poda sob o olhar da gestão dos resíduos, ou seja, do ponto de vista de uma instituição responsável pela limpeza urbana de uma grande cidade. No Rio de Janeiro temos mais de 600.000 árvores "públicas", e sua poda e remoção de galhos e raizeiros de árvores tombadas por força de fortes ventos ou mesmo por degradação do indivíduo é um imenso trabalho que poucos imaginam existir. São necessárias equipes de profissionais treinados e formados, além de muito equipamentos. Além disso, nas instituições públicas, é inimaginável a pressão política, que se sofre principalmente por parte de vereadores, para que o órgão responsável pela poda atenda a seus pedidos com prioridade. Este atendimento é uma inestimável moeda de troca política, poucos sabem disso. E como é difícil atender a todas as demandas. Uns querem que se podem as árvores deixando só o tronco, outros não querem que se toquem nos vegetais. Enfim, uma exigente e cara atividade sobre a qual posso discorrer no tempo que terei no congresso. Digamos que é uma visão nada muito científica nem botânica, mais pragmática, que inclui ainda os melhores usos que a COMLURB tenta dar aos resíduos: compostagem, combustível para cerâmicas, biometanização, confecção de móveis públicos etc.

Palavras-chave: gestão de resíduos, limpeza urbana, poda, remoção de árvores.

\begin{abstract}
It exposes the problem of pruning from the perspective of waste management, that is, from the point of view of an institution responsible for urban cleaning in a large city. In Rio de Janeiro, there are more than 600,000 "public" trees, and their pruning and the removal of branches and roots of fallen trees due to strong winds or even by degradation of the individual is an immense work that few know about. Teams of trained and formed professionals are required, as well as a lot of equipment. In addition, in public institutions, political pressure is unimaginable, which occurs mainly on the part of city councilors, so that the agency responsible for pruning meets their requests with priority. This service is an invaluable means of political bargaining that few know about. In addition, it is difficult to meet all these demands. Some want the trees to be pruned leaving only their trunk; others want the plants not to be touched. Anyway, it is a demanding and expensive activity that I can discuss in the time that I will have at the congress. Let us say that this is not a very scientific or botanical view, but a more pragmatic one, which also includes the best uses that the COMLURB tries to give to waste: composting, fuel for ceramics, biomethanization, public furniture manufacturing, etc.
\end{abstract}

Keywords: waste management, urban cleaning, pruning, tree removal. 